\title{
Maatalouden tuottavuusseuranta - laskentajärjestelmä ja tuloksia
}

\author{
Olli Rantala ${ }^{1)}$ ja Jyri Järvinen ${ }^{1)}$ \\ ${ }^{1)}$ MTT Taloustutkimus, Latokartanonkaari 9, 00790 Helsinki, etunimi.sukunimi@mtt.fi
}

\begin{abstract}
Maatalouden tuottavuudella on keskeinen merkitys yksittäisten yritysten ja koko maataloustoimialan taloudelliseen menestymiseen ja kilpailukykyyn. Yhdessä tuotteiden ja tuotantopanosten hintojen kanssa tuottavuus vaikuttaa suoraan toiminnan kannattavuuteen. Tuottavuuden nousua ja riittäviä kannusteita tuottavuuden lisäämiseen pidetäänkin välttämättöminä edellytyksinä yritysten ja koko toimialan kehittymiselle. Tuottavuuden nousu maataloudessa osana elintarvikeketjua johtaa alempiin yksikkökustannuksiin ja vaikuttaa lopulta myös kuluttajien
\end{abstract} kohtaamiin hintoihin.

Tuottavuudelle tarkoitetaan yleisesti, miten tehokkaasti tuotannossa muunnetaan tuotantopanoksia erilaisiksi tuotteiksi ja palveluiksi. Tuottavuuden kehitystä mittaavat indikaattorit perustuvat tämän fyysisen tuotantoprosessin mittaamiseen. Tuottavuuden peruspiirre on, että se ilmaistaan fyysisinä tai taloudellisina yksikköinä ja että tuottavuusluvut perustuvat mittauksiin eri tasoilla, esim. toimialan tai yrityksen tasolla.

Maatalouden tuottavuuden kehitystä on perinteisesti laskettu maa- ja puutarhatalouden kokonaislaskelmien perusteella, mutta myös yritystason aineistoihin perustuvia erillisiä tutkimuksia on jonkin verran julkaistu. Suomen maatalouden tuottavuuden kehityksestä ei ole kuitenkaan olemassa yhtenäisin perustein laadittuja tilastoja. MTT taloustutkimuksessa on kehitetty laskentajärjestelmä, joka laskee maatalouden tuottavuuden kehitystä mittaavat indikaattorit yritystason aineistosta. Suoriteperusteinen ja tarkastettu kannattavuuskirjanpitoaineisto tarjoaa laskentasovellukselle luotettavan aineistopohjan. Järjestelmä tuottaa reaaliset panosten ja tuotosten määräindeksit ja laskee kokonaistuottavuuden yrityskohtaiset tunnusluvut, jotka voidaan summata osana MTT:n Taloustohtori -analyysi-/raportointijärjestelmää edustaviksi tunnusluvuiksi halutuille ryhmätasoille tai toimialan kokonaistasolle.

Tuottavuuslaskennassa käytetään Divisia-Törnqvist -indeksilukujen menetelmää. Tuotokset ja tuotantopanokset aggregoidaan määräindekseiksi ja näiden tuotos-panos indeksien suhteen muutos osoittaa tuottavuuden muutoksen. Menetelmässä painotetaan reaalisten tuotosmäärien ja panoskäytön yksittäisiä eriä niiden keskimääräisillä tuotto- ja kustannusosuuksilla. Laskennassa käytetään noin 90 sekä tuotos- että panosmuuttujaa, joiden määrätiedot on saatu jakamalla tuotot ja kustannukset muuttujakohtaisilla hintaindekseillä. Laskentasovellus on toteutettu SAS-ohjelmalla.

Tuottavuuslaskenta tarjotaan käyttäjille Internetissä MTT:n Taloustohtori -verkkopalveluna. Räätälöidyn käyttöliittymän kautta käyttäjä voi valita haluamansa luokittelijat, jonka jälkeen erillinen sovellus suorittaa tuottavuuslaskennan ja palauttaa tulokset raporttina selaimelle. Tulokset ovat tilastollisesti painotettuja ja ne kuvaavat valitun luokittelun mukaisten ryhmien tai koko maan kaikkien tilojen keskimääräisiä tuloksia.

Asiasanat: Kannattavuuskirjanpito, kokonaistuottavuus, tunnusluvut 


\section{Johdanto}

Tuottavuus on kansantaloudessa, sen eri toimialoilla ja yrityksissä taloudellisen kasvun ja kilpailukyvyn perusta. Myös maataloudessa tuottavuudella on keskeinen merkitys yksittäisten yritysten ja koko maataloustoimialan taloudelliseen menestymiseen ja kilpailukykyyn. Yhdessä tuotteiden ja tuotantopanosten hintojen kanssa tuottavuus vaikuttaa suoraan yritysten toiminnan kannattavuuteen. Tuottavuuden nousua ja riittäviä kannusteita tuottavuuden lisäämiseen pidetäänkin välttämättöminä edellytyksinä yksittäisten yritysten ja koko toimialan kehittymiselle. Tuottavuuden nousulla maataloudessa osana elintarvikeketjua on paljon positiivisia vaikutuksia, se johtaa alempiin yksikkökustannuksiin ja vaikuttaa lopulta myös kuluttajien kohtaamiin hintoihin.

Tuottavuus määritellään yleisesti kansantalouden, toimialan tai yrityksen tuotantomäärän ja tuotannon aikaansaamiseksi käytettyjen tuotantopanosten suhteena. Tuottavuus mittaa siten, miten tehokkaasti tuotannossa muunnetaan tuotantopanoksia erilaisiksi tuotteiksi ja palveluiksi. Tuottavuuden kehitystä mittaavat indikaattorit perustuvat tämän fyysisen tuotantoprosessin mittaamiseen. Tuottavuuden peruspiirre on, että se voidaan ilmaista joko fyysisinä tai taloudellisina yksikköinä ja että tuottavuusluvut perustuvat mittauksiin eri tasoilla, esim. toimialan tai yrityksen tasolla.

Maatalouden tuottavuuden kehitystä on perinteisesti laskettu maa- ja puutarhatalouden kokonaislaskelmien perusteella, mutta myös yritystason aineistoihin perustuvia erillisiä tutkimuksia on jonkin verran julkaistu mm. Tilastokeskuksen ja MTT:n julkaisuissa. Suomen maatalouden tuottavuuden kehityksestä ei ole kuitenkaan olemassa yhtenäisin perustein laadittuja tilastoja.

MTT taloustutkimuksessa on kehitetty laskentajärjestelmä, joka laskee maatalouden tuottavuuden kehitystä mittaavat indikaattorit yritystason aineistosta. Suoriteperusteinen ja tarkastettu kannattavuuskirjanpitoaineisto tarjoaa laskentasovellukselle luotettavan aineistopohjan. Järjestelmä tuottaa reaaliset panosten ja tuotosten määräindeksit ja laskee kokonaistuottavuuden yrityskohtaiset tunnusluvut, jotka voidaan summata osana MTT:n Taloustohtori -analyysi-/raportointijärjestelmää edustaviksi tunnusluvuiksi halutuille ryhmätasoille tai toimialan kokonaistasolle. Tuottavuuslaskenta tarjotaan käyttäjille Internetissä MTT:n Taloustohtori-verkkopalvelussa.

\section{Tuottavuuden kehitys Suomen maataloudessa}

Vallitseva trendi parin viime vuosikymmenen aikana maataloudessa on ollut melko vakaa tuotannon volyymi ja pääosin työpanoksen laskusta johtunut aleneva tuotantopanosten käyttömäärä. Maatalouden kokonaislaskelmien aineistosta Divisia indeksi-menetelmällä laskettu tuottavuuden nousu oli keskimäärin 1,2 \% vuotta kohti vuosina 1992 - 2010. Vuonna 2010 saman tuotantomäärä saatiin aikaan $19 \%$ pienemmällä panosmäärällä kuin vuonna 1992. Tuotannon volyymi oli $96 \%$ ja tuotantopanosten käyttömäärä $78 \%$ vuoden 1992 tasosta. Varsinkin työn tuottavuus on noussut ripeästi, keskimäärin noin $5 \%$ vuodessa. Yhtä työpanosyksikköä kohti saatiin vuonna 2010 aikaan 2,3 kertaa suurempi tuotantomäärä kuin vuonna 1992. Maataloudessa kokonaistyöpanos väheni 160000 AWU:sta noin 70000 AWU:uun eli $56 \%$. Pääoman tuottavuudessa maataloudessa ei ole pitkällä aikavälillä tapahtunut juurikaan muutosta (Myyrä 2011).

Yrityskohtaisesta kirjanpitoaineistosta laskettu kotieläintilojen tuottavuus on ollut positiivista EU-kaudella. Ripeä rakennekehitys ja uudemman teknologian käyttöönotto investointitukien vauhdittamana on nopeuttanut tuottavuuden kasvua. Kasvintuotannossa tuottavuus oli erittäin huono varsinkin 1990-luvulla, mutta on viime vuosina satojen nousun myötä parantunut. Erityisesti matalien hintojen aikoina kasvintuotannossa ei nähdä olevan riittävästi kannusteita tuottavuuden parantamiseen.

Suomen maatalouden tuottavuuden taso on eräiden tutkimusten mukaan alempi kuin keskeisissä maatalousmaissa EU-alueella, mikä johtuu lähinnä epäedullisista luonnonoloista ja heikosta yritysrakenteesta. Saman kokoluokan Suomen maitotilojen tuottavuusero esim. Tanskaan verrattuna on $20-30 \%$ ja Etelä-Ruotsiin 10 - $20 \%$ (Sipiläinen 2008). Saman tuotantomäärän aikaansaamiseksi Suomen maitotiloilla tarvitaan siten selvästi suurempi tuotantopanosten käyttömäärä kuin näissä vertailumaissa. 


\section{Laskentamenetelmä}

Tuottavuuden laskennassa käytetään Divisia-Törnqvist -indeksilukujen menetelmää. Siinä yksittäiset tuotos- ja tuotantopanosmäärät aggregoidaan määräindekseiksi ja näiden tuotos-panos indeksien suhteen muutos osoittaa tuottavuuden muutoksen. Menetelmässä painotetaan reaalisten tuotosmäärien ja panoskäytön yksittäisiä eriä niiden keskimääräisillä tuotto- ja kustannusosuuksilla.

$$
T F P_{t, t_{-1}}=\frac{\text { Output Index } t_{,} t_{-1}}{\text { Input Index } t t_{-1}}
$$

Divisia TFP-indeksi muutokselle vuodesta t-1 vuoteen t ilmaistaan yleisesti:

$$
\ln \frac{T F P_{t}}{T F P_{t_{-}}}=1 / 2 \sum\left(r_{i, t}+r_{i, t_{-} 1}\right) \ln \left(\frac{Y_{i, t}}{Y_{i t_{-}}}\right)-1 / 2 \sum\left(s_{j, t}+s_{j, t}{ }_{1}\right) \ln \left(\frac{X_{j, t}}{X_{i} t_{-1}}\right)
$$

Kaavassa $Y_{i}$ on tuotos $i$ ja $X_{j}$ on panos $j, r_{i}$ ja $s_{j}$ ovat niiden vastaavat tuotto- ja kustannusosuudet. Peräkkäisten vuosien tuotossuhteiden summista vähennetään vastaavat panossuhteiden summat, molemmat painotettuina vastaavilla tuotto- ja kustannusosuuksilla.

\section{Aineisto ja hinnat}

Laskennassa on nyt käytössä kaikkiaan 88 tuotosmuuttujaa ja 91 panosmuuttujaa. Tuottoihin ei lueta mukaan tukia. Panosmuuttujiin sisältyvät kaikki tuotantokustannuksiin laskettavat erät ml. oman työn palkkakustannus ja oman pääoman laskennallinen korkokustannus. Tuotosten ja panosten reaaliset määrätiedot on saatu jakamalla tuotto- ja kustannuserät muuttujakohtaisilla hintaindekseillä. Hintaindekseinä on käytetty Tilastokeskuksen maatalouden tuottaja- ja tuotantovälineiden ostohintaindeksejä sekä TIKEn kokoamia hintatilastoja. Myös eräitä muita lähteitä on käytetty mm. puutarhatuotteiden, energian ja palkkavaatimuksen hintatietojen määrittämisessä. Ennustevuosien hintatiedot on laskettu regressiomalleilla $\mathrm{mm}$. viljakasveille tai käyttäen jotain muuta soveltuvaa menetelmää.

\section{Yrityskohtaiset indeksit ja ryhmäkeskiarvot}

Laskentasovellus tuottaa yrityskohtaiset reaaliset tuotosten ja panosten määräindeksit ja laskee niiden perusteella kokonaistuottavuuden tunnusluvut. Yrityskohtaiset tunnusluvut mahdollistavat tuottavuuden tason vertailun erilaisten tilaryhmien välillä ja antavat samalla tietoa tuottavuuden kehityksestä pitkällä aikavälillä, jolloin tuotos- ja panosrakenne voi yritystasollakin muuttua suuresti teknologian ja hintamuutosten seurauksena.

Yritystason tuottavuusindeksit voidaan summata MTT:n Taloustohtorin analyysi/raportointijärjestelmää käyttäen edustaviksi tunnusluvuiksi halutuille ryhmätasoille tai toimialan kokonaistasolle. Laskettaessa tietyn vuoden ryhmäkeskiarvoja painotetaan tilojen luvut niiden panosmäärillä, jolloin suurempi tila saa suuremman panoskäyttönsä seurauksena keskiarvoa laskettaessa suuremman painon. Laskettaessa tuottavuuden keskimäärästä muutosta vuosien yli, on mahdollista käyttää vaihtoehtoisia menetelmiä. Nyt on käytetty lähinnä suoria keskiarvoja ja trendejä, mutta myös erilaisia tasoitusmenetelmien ja liukuvien keskiarvojen käyttöä on kokeiltu. 


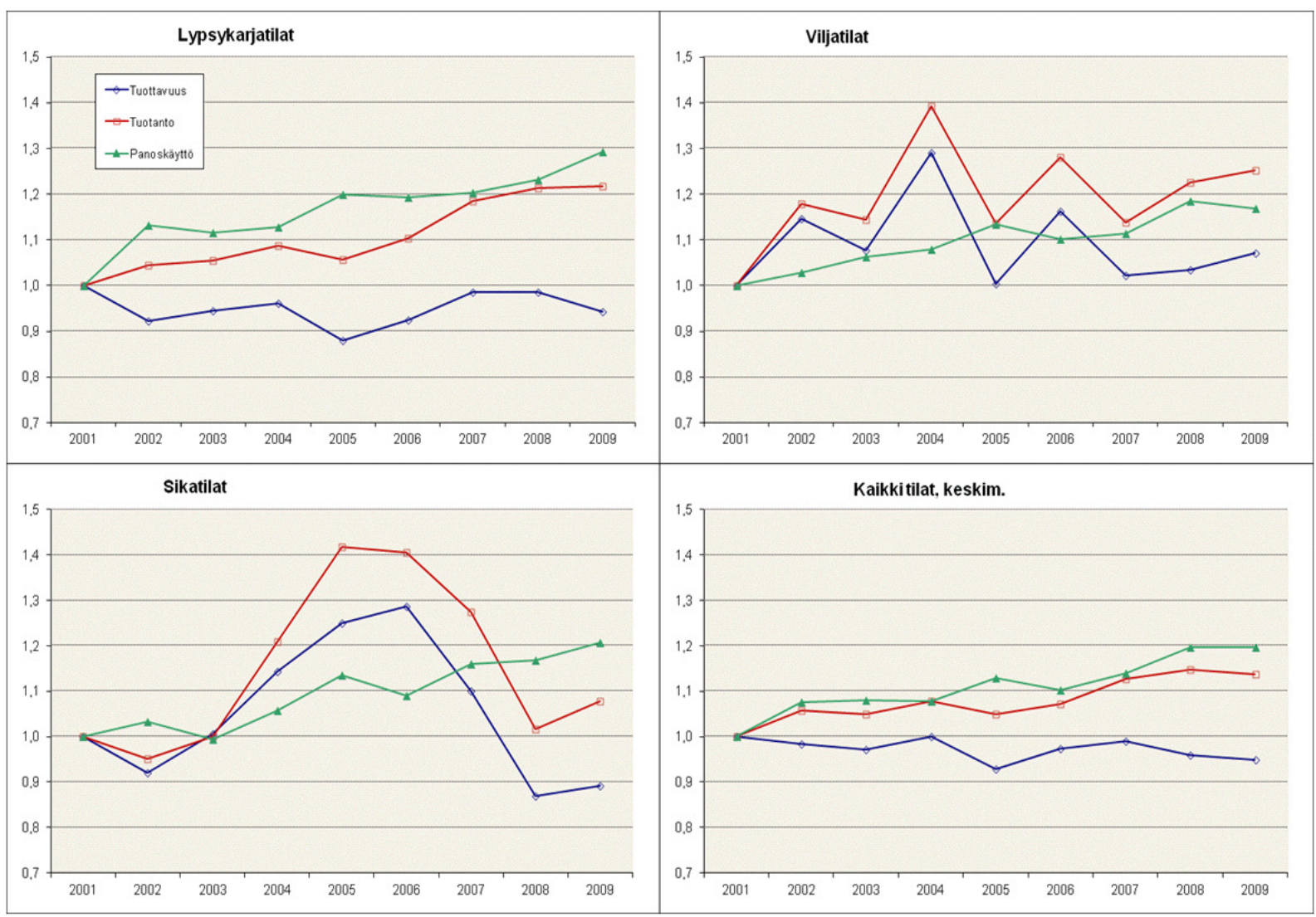

Kuvio 1. Maatalouden tuottavuusindeksit vuosina 2001 - 2009 eri tuotantosuunnissa ja kaikilla tiloilla keskimäärin (alustavia tuloksia).

\section{Tulosten raportointi}

Tuottavuuslaskenta on suunniteltu tarjottavaksi käyttäjille Internetissä MTT:n Taloustohtori verkkopalvelussa. Teknisesti järjestelmä on tehty Taloustohtori-alustalle, joka tarjoaa sille käyttöliittymän, perusaineiston ja raportointiympäristön. Varsinainen tuottavuuslaskenta on erillinen SAS-koodilla tehty ohjelma, jota järjestelmä käyttää ulkoisena sovelluksena. Omana palveluna toteutettuna verkkopalveluna käyttäjä antaa käyttöliittymän kautta haluamansa luokittelijat ja saa tulosteena raportin selaimelle. Raportti sisältää tuotosten ja panosten määräindeksit ja tuottavuusindeksit valitun ajanjakson vuosille, jossa ensimmäinen vuosi on laskennan perusvuosi ja sen indeksiluku on 1. Kuten kaikki muutkin Taloustohtorin analyysi-/raportointijärjestelmässä raportoitavat ryhmäkeskiarvot myös tuottavuusindikaattorit lasketaan painotettuina keskiarvoina, joten ne kuvaavat vastaavien ryhmien tai koko maan kaikkien tilojen tuloksia. 


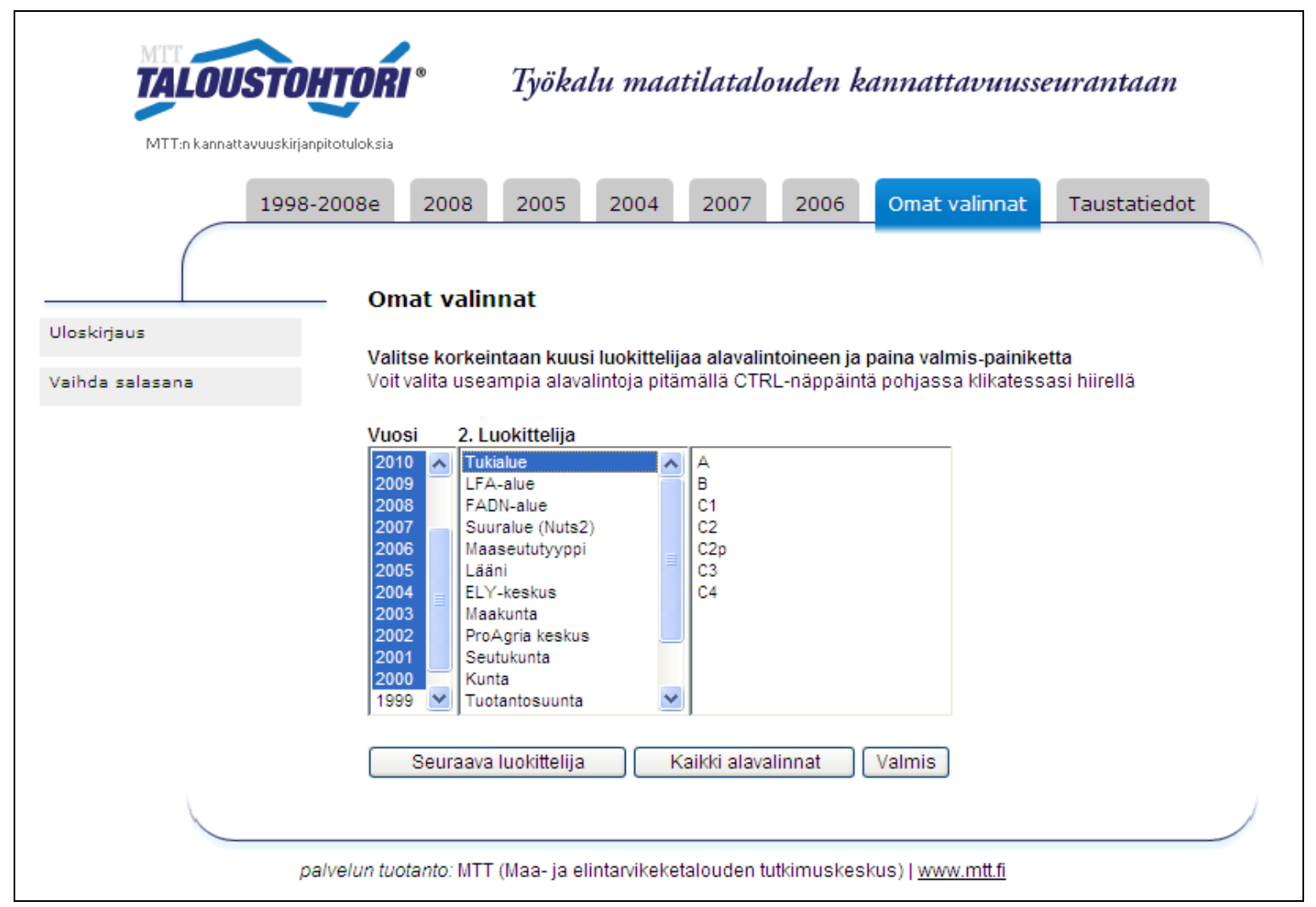

Kuvio 2. Tuottavuuslaskennan MTT:n Taloustohtori-verkkopalvelun käyttöliittymä

\begin{tabular}{|c|c|c|c|c|c|c|c|c|c|}
\hline Tuottavuus & 2001 & 2002 & 2003 & 2004 & 2005 & 2006 & 2007 & 2008 & 2009 \\
\hline Tiloja edustettuna & 48400 & 48200 & 46800 & 45900 & 44300 & 42800 & 40800 & 39600 & 38000 \\
\hline Kirjanpitotiloja & $830<n<840$ & $810<\mathrm{n}<820$ & $810<n<820$ & $850<n<860$ & $890<n<900$ & $910<n<920$ & $930<n<940$ & $920<n<930$ & $930<n<940$ \\
\hline Viljelyala & $\ldots$ & $\ldots$ & $\ldots$ & $\ldots$ & $\ldots$ & $\ldots$ & $\ldots$ & $\ldots$ & $\cdots$ \\
\hline Eläinyksiköt & $\cdots$ & $\ldots$ & $\ldots$ & $\ldots$ & $\cdots$ & $\ldots$ & $\cdots$ & $\ldots$ & $\cdots$ \\
\hline Tuottavuus & 1 & 1,097 & 0,984 & 0,578 & 0,964 & 1,059 & 1,048 & 1,071 & 1,031 \\
\hline Tuotanto & 1 & 1,186 & 1,044 & 1,168 & 1,061 & 1,136 & 1,141 & 1,194 & 1,156 \\
\hline Panoskaytto & 1 & 1,081 & 1,061 & 2,020 & 1,101 & 1,073 & 1,088 & 1,115 & 1,122 \\
\hline
\end{tabular}

Kuvio 3. Esimerkki tuottavuuslaskennan tulostuksesta, järjestelmän selaimelle palauttama raportti

\section{Lähteet}

Coelli, T., Prasada Rao, D., O’Donnell, C., Battese, G. 2005. An introduction to efficiency and productivity analysis. 353 p. Springer Science+Business Media.

Myyrä, S. 2011. Maatalouden tuottavuuskehitys. Suomen maatalous ja maaseutuelinkeinot 2011, s. 62-63.

Sipiläinen, T. 2008. Maatalouden tuottavuuskehitys. Suomen maatalous ja maaseutuelinkeinot 2008, s. 55-57. 